\title{
Hong Kong After the Umbrella Movement
}

An uncertain future for "One Country Two Systems"

\section{Samson Yuen}

\section{OpenEdition}

\section{Journals}

Electronic version

URL: http://journals.openedition.org/chinaperspectives/6656

DOI: 10.4000/chinaperspectives.6656

ISSN: 1996-4617

\section{Publisher}

Centre d'étude français sur la Chine contemporaine

\section{Printed version}

Date of publication: 1 March 2015

Number of pages: 49-53

ISSN: 2070-3449

\section{Electronic reference}

Samson Yuen, « Hong Kong After the Umbrella Movement », China Perspectives [Online], 2015/1 | 2015, Online since 01 January 2017, connection on 15 September 2020. URL : http:// journals.openedition.org/chinaperspectives/6656 


\title{
Cefe News Analysis
}

\section{Hong Kong After the Umbrella}

\section{Movement:}

\author{
An uncertain future for "One Country Two Systems"
}

\section{SAMSON YUEN}

B efore police in riot gear fired rounds of tear gas at unarmed protesters on September 28, few could have expected that the siege of the government headquarters would turn the scripted Occupy Central (zhanling zhonghuan 佔領中環) into Hong Kong's biggest and most unprecedented pro-democracy movement amidst its electoral reforms. ${ }^{(1)}$ In the next twoand-a-half months, protesters of what became the Umbrella Movement (yusan yundong 雨傘運動) (2) would occupy major roads in the city's busiest districts, set up tents, stock up supplies, and protect their territories with makeshift barricades, sometimes with human chains, to stop police incursion and opposing groups. Across the encampments, they would press on for a focused goal - "genuine universal suffrage" (zhen puxuan 真普選) for election of their Chief Executive, the city's top leader - until police officers cleared the last occupied site on December 15. This article assesses the implications of the Umbrella Movement as it drew to a close. It explains how the movement morphed from the Occupy Central movement, and reviews the controversy raised over the city's rule of law and constitutional relations with mainland China. Despite having amplified democracy supporters' yearnings for universal suffrage, the movement, in which no compromise was offered by Beijing and the Hong Kong government, will likely deepen social cleavages and send the city toward an uncertain future.

\section{From Occupy Central to the Umbrella Movement}

The Umbrella Movement was set against a protracted debate over the electoral reform of the city's Chief Executive election. According to the National People's Congress ruling in 2007, Hong Kong may finally introduce universal suffrage for the election of the fifth Chief Executive in 2017 - after it was twice denied by Beijing for its 2007 and 2012 elections. ${ }^{(3)}$ If universal suffrage is implemented in 2017, Chief Executive candidates would be elected by a popular vote instead of being selected by an election committee - but they must be selected by a nominating committee to ensure that the elected leader would not oppose the central government and that he/she would "love the country and love Hong Kong" (aiguo aigang 愛國愛港), a requirement set out by numerous Chinese officials. In addition, Hong Kong's Basic Law requires this nominating committee to be "broadly representative" and to operate "in accordance with democratic procedures," but it does not clearly outline the composition of the committee or the nomination procedure. ${ }^{(4)}$

The nomination process soon became the focal point of contention. Across the pro-democracy camp, there were widespread concerns that the nomination process will act as a safety valve to screen out candidates regarded unfavourably by Beijing. Fearing that the election might turn out to be "fake universal suffrage" (jia puxuan 假普選), democracy supporters argued that they have not only the right to be elected but also the right to be nominated, and thus they deserve a more democratic and inclusive nomination process. ${ }^{(5)}$ Many insisted on the introduction of civic nomination (gongmin timing 公民提名), a mechanism that would allow the public to bypass the nominating committee and directly nominate Chief Executive candidates, but which has been rejected by the government as a contravention of the Basic Law. (6) Some would accept a more democraticallyformed nominating committee, as long as there was reform on its composition and/or a reasonably lower nomination threshold.

1. All links in the footnotes were accessed on 5 January 2015

2. Foreign media originally coined the term "Umbrella Revolution" because of protesters' use of umbrellas to defend themselves against police incursion. The term quickly became a popular hashtag across the Internet. But OCLP organizers and local scholars rejected the name, arguing that "revolution" carries the connotation of overthrowing the government, which was not the intention of the mass protest, and might prompt Beijing to over-react. The term "Umbrella Movement," they argue, would be a more neutral way to characterise the Occupy protest. See, for example, Chris Yeung, "Don't Call Hong Kong's Protests an 'Umbrella Revolution'," The Atlantic, 8 October 2014, available at http://www.theatlantic.com/international/archive/2014/10/dont-call-hongkongs-protests-an-umbrella-revolution/381231/.

3. Josh Noble, "Hong Kong sets in motion overhaul of electoral system," Financial Times, 15 July 2014, available at http://www.ft.com/intl/cms/s/0/d87a0b04-0bf2-11e4-9080-00144feabdc0 .html\#axzz3NwNAAOIC; "Full text of NPC decision on Hong Kong's constitutional development," Standing Committee of the Tenth National People's Congress, 29 December 2007.

4. Article 45 of Hong Kong's Basic Law states: "The Chief Executive of the Hong Kong Special Administrative Region shall be selected by election or through consultations held locally and be appointed by the Central People's Government. The method for selecting the Chief Executive shall be specified in the light of the actual situation in the Hong Kong Special Administrative Region and in accordance with the principle of gradual and orderly progress. The ultimate aim is the selection of the Chief Executive by universal suffrage upon nomination by a broadly representative nominating committee in accordance with democratic procedures." See http://www.basiclaw gov.hk/en/basiclawtext/chapter_4.html.

5. See a summary of different electoral proposals on the 2017 CE election at http://www.ictls.com/ $\mathrm{php} / \mathrm{wp} 2 /$ ? $\mathrm{p}=8778$.

6. "Civic nomination not a must for democracy," Hong Kong Information Service Department, 24 October 2014, available at http://www.news.gov.hk/en/categories/admin/html/2014/ 10/20141024_133803.shtml. 
The idea of Occupy Central was floated amidst the debate. In early 2013, law professor Benny Tai Yiu-ting sketched the early vision of Occupy Central in a series of newspaper articles and interviews. ${ }^{(7)}$ Tai proposed a large-scale civil disobedience (gongmin kangming 公民抗命) movement in which participants would block traffic to petition for universal suffrage in the CE election that would comply with "international standards." (8) According to its final plan, protesters would stage a peaceful sit-in on a major road in Central, Hong Kong's financial heart, for two to three days until their orderly removal and arrest by the police - hence the name "Occupy Central with Love and Peace" (OCLP, rang ai yu heping zhanling zhonghuan 讓愛與和平 佔領中環) to mark the rational and non-violent nature of civil disobedience. Tai's proposal was at first welcomed by democracy supporters for its spirit and novelty, only to gain lukewarm support after it was criticised for being too radical and impractical on the one hand, and too docile, self-limiting, and distant from the youth on the other. ${ }^{(9)}$

On 31 August 2014, the National People's Congress issued a "decision" that set out further guidelines for the 2017 CE election. ${ }^{\left({ }^{10}\right)}$ According to the "decision," the nominating committee must be formed "in accordance with" the existing 1,200-strong four-sector election committee, which had been criticised for over-representing the interests of Beijing and the business sector. In addition, the new committee will only nominate two to three candidates for the final runoff, each of whom must secure support from more than half of the nominating committee members - four times the existing one-eighth threshold. The NPC decision gave new impetus to the waning Occupy Central movement and escalated tensions as pro-democracy supporters saw the decision as a blatant denial of "genuine universal suffrage," although the government urged lawmakers to accept the current package, or to "pocket what they have" (daizhu xian 袋住先). On September 22, Scholarism (xuemin sichao 學民思潮) and the Hong Kong Federation of Students ( xuelian 學聯) - two civic groups formed by high school and university students, respectively - launched a weeklong class boycott at the Tamar government headquarters to demand the withdrawal of the NPC decision. It was also intended as an informal prelude to OCLP, which was anticipated to begin on the 1 October National Day. ${ }^{(11)}$

However, two spontaneous events turned the scripted movement into an improvised mass protest that surpassed imagination. The first was the attempt to "recapture Civic Square" (chongduo gongmin guangchang 重奪公 民廣場), the government office's forecourt, which was blocked off by fences after the anti-national education movement (fanguojiao yundong 反國教 運動) was staged in 2012. On the night of 26 September, a group of students climbed over the metal fences and stormed the empty forecourt, claiming that the space belonged to the public. The students were swiftly surrounded and arrested by the police, but the move dramatically backfired. The next day, thousands of angry protesters swamped the government headquarters shouting for the release of the arrested student leaders along with slogans for genuine universal suffrage. The unexpected mobilisation around the government offices motivated OCLP leaders to launch the movement ahead of its proposed schedule, and also at a different location - Admiralty instead of Central.

But what turned OCLP into the Umbrella Movement was a more disturbing event on September 28. As protesters flooded the roads outside the government headquarters as a result of the police blockade, police officers in riot gear fired 87 canisters of tear gas in an attempt to dispel protesters. Images of protesters wearing mask and goggles while hiding behind umbrellas to protect themselves against tear gas and pepper spray were broadcasted on
TV and spread rapidly on social media, prompting more angry crowds to take to the streets. ${ }^{(12)}$ Within hours, protesters armed with goggles, facemasks, and umbrellas inundated Admiralty. Some even extended the "battlefront" to Causeway Bay and Mong Kok - the city's two main shopping districts where thousands of protesters launched sit-ins on the main roads.

What became of the original Occupy Central movement was an improvised 79-day occupation of Admiralty, Causeway Bay, and Mong Kok, jointly led by the Hong Kong Federation of Students, Scholarism, and OCLP. Each occupied district developed its own characteristics: Admiralty for its distinct middleclass character with strong student and civic group involvement, Mong Kok for its grassroots and triad involvement, and Causeway Bay for its popularity with tourists. All of them became self-sufficient communities that protesters referred to as "villages" (cun 村), filled with art installation and makeshift structures such as camps, study areas, and supply stations, in which protesters pressed on for a genuine universal suffrage. Nevertheless, although the movement amplified protesters' democratic yearnings and will likely give rise to a more politically active populace, it has raised at least two issues that will continue to be controversial and divisive, especially in light of the absence of any concessions from the Hong Kong government or Beijing.

\section{Two conceptions of the rule of law}

One of the most contentious issues during the movement concerns the city's long-cherished rule of law. From the beginning, government officials and the pro-establishment camps had gone all out to undermine the legitimacy of the Occupy Central movement, condemning it as unlawful, detrimental to the rule of law, and disruptive to social order. Chief Executive C.Y. Leung, for example, attacked the movement as an unlawful action to coerce the central and Hong Kong governments by paralysing core areas of the city, saying that the government had no right to require the NPC to retract the August decision. ${ }^{(13)}$ Beijing took a similar line. As soon as protesters occupied the streets, the State Council's Hong Kong and Macau Affairs Office said that the central government firmly opposed all illegal activities that could undermine the rule of law and jeopardise social order, a message that would become the official framing of the Occupy protests in the mainland press. ${ }^{(14)} \mathrm{A}$ People's Daily front-page editorial on 1 October argued that the Occupy protests were illegal and hurting Hong Kong's rule of law, warning of "unimaginable consequences" if the protests continued and stressing that Beijing stance on Hong Kong's elections was "unshakable" and legally valid. (15)

7. Benny Tai, "Gongmin kangming de zuida shashangli wuqi" (The most destructive weapon of civil disobedience), Hong Kong Economic Journal, 16 January 2013; Melody Chan, "Yifa dayi: gongmin kangming de zhadan - zhuanfang Dai Yaoting" (Justice through law:The bomb of civil disobedience - an interview with Benny Tai), Independent Media, 22 January 2013, available at http://www.inmediahk.net/node/1015347.

8. Karita Kan, "Occupy Central and Constitutional Reform in Hong Kong," China Perspectives, 2013/3, pp. 73-78.

9. Ibid.

10. "Full text of NPC decision on universal suffrage for HKSAR chief selection," Xinhua, 31 August 2014.

11. Jeffie Lam and Clifford Lo, "Occupy Central leader drops 'grand banquet' hint that protest will start October 1," SCMP, 24 September 2014.

12. Gary Tang Kin-yat, "Shei dongyuan qunzhong" (Who mobilised the mass?), Ming Pao, 27 November 2014.

13. Gary Cheung, Shirley Zhao, and Adrian Wan, "Hong Kong government resolutely opposed to Occupy Central, says chief executive CY Leung," SCMP, 29 September 2014.

14. Ibid.

15. "Zhenxi lianghao fazhan jumian, weihu Xianggang fanrong wending" (Cherish the good development prospect, defend Hong Kong's prosperity and stability), People's Daily, 1 October 2014. 
Other reports and editorials in the Chinese media have weighed in on the movement, comparing the Occupy protests to the Colour Revolutions with interference from foreign forces, calling protesters "radical activists," and even accusing them of plotting an independence movement. While there was a heated debate among analysts on how Beijing actually characterised (dingxing 定性) the protests, Beijing's official stance seemed to focus on the illegal nature of the movement and its erosion of the rule of law. The emphasis on the illegality of the Occupy protest also became an opportunity for Beijing to showcase its national agenda to promote "ruling the country according to law" (yifa zhiguo 依法治國), a major theme under Xi Jinping's administration. (16)

Indeed, there is a legal basis for regarding Occupy Central as unlawful. Organisers of OCLP have pointed out that participants of Occupy Central could be guilty of "obstructing, inconveniencing or endangering a person or vehicle in a public place" under the Summary Offenses Ordinance. (17) In addition, by blocking roads, the Occupy protests could be considered unauthorised or unlawful assembly under the Public Order Ordinance. Participants could be charged with taking part in or organising an "unauthorised assembly" if it is a meeting of more than 50 persons, which has not been granted a Letter of No Objection from the Commissioner of Police. Even if the Occupy protest had received permission from the police, participants could still be charged with "unlawful assembly" if three or more people assemble "in a disorderly, intimidating, insulting or provocative manner" or provoke other people to "commit a breach of the peace" - or if police judge that a breach of the peace is likely to occur. ${ }^{(18)}$

For leaders of OCLP, however, breaking the law is an essential part of the civil disobedience movement and is crucial for amplifying protesters' call for democracy. In an earlier book, Benny Tai proposed a rule of law pyramid that explains his vision of the rule of law with four ascending levels of progress: (1) existence of law, (2) regulation by law, (3) limitation by law, and (4) justice through law. ${ }^{(19)}$ For Tai, while the first two levels guarantee that people obey the law, it is justice through law (yifa dayi 以法達義), which lies at the top echelon, that achieves different conceptions of justice using the law - including procedural justice, civil rights justice, social justice, and deliberative justice. However, if the law fails to deliver justice or entrenches injustice, then it is necessary to achieve justice through breaking the law (weifa dayi 違法達義). (20) As Tai wrote in an op-ed, "If law cannot resolve the factors that lead to civil disobedience... [then] civil disobedience is necessary to provide the opportunity to change the content of the law." (21)

This does not change the unlawful nature of civil disobedience, Tai added, which protesters must acknowledge and accept - as was exemplified by a group of Occupy protesters, including Tai and other OCLP organisers, who surrendered themselves to the police on December 3. However, despite acknowledging the unlawful nature of their actions, they rejected the view that civil disobedience has undermined the city's rule of law. ${ }^{(22)}$ Michael Davis, a law professor at the University of Hong Kong, explained why the Occupy protests might have broken the law but not undermined the rule of law. In his newspaper column, Davis argued:

It is important here to distinguish between breaking the law and undermining the rule of law. The non-violent protesters have clearly broken the law by not complying with the Public Order Ordinance and, further, by not clearing those areas covered by court orders. Both are purposeful law-breaking in furtherance of a non-violent civil dis- obedience campaign. We should bear in mind that civil disobedience by definition involves breaking the law in support of a higher ideal that is the aim of the civil disobedience campaign. ${ }^{(23)}$

Davis put forward the view that governments are more likely to harm the rule of law:

By putting the Standing Committee above the law and redefining basic human rights guarantees in an unrecognisable manner, the State Council and the Standing Committee have put Hong Kong's high degree of autonomy and rule of law in jeopardy. The failure of the local government to guard Hong Kong's high degree of autonomy and its seemingly complicit role in the Standing Committee's decision implicates it as well. (24)

Davis' view that breaking the law does not necessarily undermine the rule of law was supported by other legal scholars who were sympathetic to the movement. ${ }^{(25)}$ But the Hong Kong Bar Association appeared to disagree. As the High Court granted civil injunctions to several private groups ordering protesters to clear sections of the occupied roads in late October, the highly respected barristers' organisation criticised protesters for calling for an open defiance of injunctions, contending that such mass disobedience had "overstepped the mark." "When deliberate defiance of a court order is committed en masse as a combined effort, a direct affront to the Rule of Law will inevitably result," the statement said, adding that "every resident - from those filled with the most noble ideas to those seeking only the most menial advantage - are governed by and bound to the operation of the law." (26)

Critics, however, questioned the attempt to use the courts to resolve political issues. One op-ed contributor wrote that "the movement is a social/political issue requiring a social/political solution, instead of pretending it is a law-and-order issue to be solved by the police, or a rule-of-law issue to be solved by the law courts." (27) Mr. Justice Henry Litton, a non-

16. "Zhonggong zhongyang guanyu quanmian tuijin yifa zhiguo ruogan zhongda wenti de jueding" (CCP Central Committee Decision Concerning Several Major Issues in Comprehensively Advancing Governance According to Law), 4th Plenary Session of the 18th Central Committee of the Chinese Communist Party, 23 October 2014, available at http://news.xinhuanet.com/politics/201410/28/c_1113015330.htm.

17. "OCLP - Manual of Disobedience," http://oclp.hk/?route=occupy/eng_detail\&eng_id=28.

18. For CAP 245 Public Order Ordinance, see http://www.legislation.gov.hk/blis_pdf.nsf/6799 165D2FEE3FA94825755E0033E532/14B03C325D4C1827482575EE0052311E?OpenDocument\&bt $=0$.

19. Benny Tai, Fazhixin: chaoyue tiaowen yu zhidu de falü jiazhi (Passion for Rule of Law:Values beyond Legal Text and Legal Institutions), Hong Kong Educational Publishing Co, 2012; for the book summary, see http://roleprojecthku.blogspot.hk/2012/12/rule-of-law-pyramid-by-associate.html.

20. Benny Tai, "Fansi gongmin kangming yu fazhi" (Reflecting on civil disobedience and the rule of law), Ming Pao, 12 November 2014.

21. Ibid.

22. Ernest Kao and Joyce Ng, "Benny Tai says Occupy Central has not undermined Hong Kong's rule of law," SCMP, 12 November 2014.

23. Michael Davis, "Occupy protests breaking law, but not undermining Hong Kong's rule of law," SCMP, 7 November 2014.

24. Ibid.

25. "No proof Occupy denting rule of law, for now: Albert Chen," EJ Insight, 29 October 2014; "Occupy Central will not undermine rule of law: HKU law dean," EJ Insight, 21 July 2014.

26. Statement of Hong Kong Bar Association in respect of "Mass Defiance of Court Orders," Hong Kong Bar Association, 28 October 2014, available at http://hkba.org/whatsnew/misc/ 20141028\%20-\%20Statement\%20of\%20Hong\%20Kong\%20Bar\%20Association\%20Relating\%20to\%20Mass\%20Defiance\%20of\%20Court\%20Orders\%20(Eng)\%20-\%20FINAL1.pdf.

27. Stephanie Cheung, "Hong Kong needs a political solution, not a legal one, to Occupy protests," SCMP, 14 November 2014. 
permanent judge of the Court of Final Appeal, questioned the "curious" handling of applications for injunctions to clear the Occupy site in Mong Kok, describing it as a civil court process invoked for what he felt was a public order issue. ${ }^{(28)}$ But the question was dismissed by Secretary for Justice Rimsky Yuen Kwok-keung, who insisted that the government has no intention of using the courts to resolve political problems. ${ }^{(29)}$ Yuen's view was largely in line with the Hong Kong Bar Association, which considered the court injunctions to be a purely civil matter. "The court has to be involved [...] because the rights of private citizens protected by the law are said to be threatened and they seek redress," its 28 October statement said. (30)

This brings out two conceptions of the rule of law at odds with each other For critics of the Occupy movement, rule of law is closer to rule by law. Under such a conception, the law must be obeyed under all circumstances, and a breach of the legal code will harm the rule of law. For supporters, the rule of law is more than just the absolute obedience to law. Rather, the law can be challenged through civil disobedience, that is, by breaking unjust laws while bearing the legal consequences. Nevertheless, these conflicting views eventually came to an abrupt end as the police cleared the last protest site in Causeway Bay on 15 December. Chief Executive C.Y. Leung declared the "illegal occupation" over and urged Hong Kong to pursue "democracy with the rule of law" - but the debate on the legality of the Occupy protest and the rule of law remained unresolved.

\section{Mainland-Hong Kong constitutional relations}

A less debated but equally important issue concerns the impact of the Occupy protest on "One Country, Two Systems" and the future relations between Hong Kong and mainland China. The key question is whether the movement will result in Beijing's tighter grip on the semi-autonomous region and whether it will be more difficult for Hong Kong to achieve a greater degree of democracy. Analysts have quoted sources saying that China's state security officials beefed up their presence in Hong Kong because of the protests. ${ }^{(31)}$ Others have raised concerns over Beijing's possible steps to assert greater control in Hong Kong, such as by increasing surveillance, influencing the media, building stronger united front networks, and swaying appointments of officials and academics. (32) Most recently, in response to Britain's inquiry into the 30-year-old Sino-British Joint Declaration, Beijing claimed that Britain has neither a role in the 50 -year pledge to keep Hong Kong's way of life intact nor a moral duty towards Hong Kong. (33)

China's tightening grip on Hong Kong is congruent with its recent policy in the SAR, as fully revealed by a White Paper published by the State Council in June 2014, which defined the city's high degree of autonomy as "the power to run local affairs as authorized by the central leadership." (34) For Beijing, the fundamental concern for granting genuine universal suffrage over which the central government has no or little control is the potential threat it poses to China, given the region's proximity to and influence on the mainland. A fully democratic Hong Kong where Hong Kongers freely elect their leaders and lawmakers would erode Beijing's sovereignty over the region and threaten the rule of the Communist Party by "turning the city into a base and the bridgehead to subvert the Mainland's socialist system" where "foreign forces" (waiguo shili 外國勢力) could meddle, in the words of one senior Chinese official. ${ }^{(35)}$ Above all, in the absence of an antisecession law, a yet unfulfilled requirement stipulated by Article 23 of the Basic Law, the introduction of complete democracy in the region could - in
Beijing's perspective - make China's national security vulnerable. Hence, the future Chief Executive must be trusted by the central government, and for that to happen, there must be a screening mechanism to ensure that candidates who oppose Beijing will not be elected. ${ }^{(36)}$

As local international relations scholar Simon Shen Xu-hui interpreted from a realist's perspective, the issue at stake is no longer universal suffrage but an inherent conflict in the principle of "One Country, Two Systems." (37) Shen's view is that Beijing considers local matters in Hong Kong, including its elections, under a broad conception of "national interest" (guojia liyi 國 家利益), which could be redefined to suit the needs of the central government. By contrast, Hong Kong people see "One Country, Two Systems" as a guarantee of their high degree of autonomy, according to which they could run local affairs without intervention from Beijing - including the election of their Chief Executives. Under the rule of Xi Jinping, however, Hong Kong affairs are regarded as an integral part of national security, placed under the remit of the newly established National Security Commission (guojia anquan weiyuanhui 國家安全委員會). Given the escalating tensions between Beijing and Hong Kong's pro-democracy camp, Shen believes there is little room to reconcile their conflicting views on "One Country, Two Systems." The Occupy protest presented a rare opportunity for Beijing to "lure the snake from its hole" (yinshe chudong 引蛇出洞) (i.e., to identify people who oppose the Party) and gauge the commitment of its loyalists. This may have been reflected in the immediate expulsion of James Tien from the Chinese People's Political Consultative Conference after his high-profile call for C.Y. Leung to consider resigning as Chief Executive. ${ }^{(38)}$ Shen argued that Beijing's main concern is no longer the electoral method of the 2017 CE election, but a comprehensive overhaul of its administrative, political, and economic structure (chongzu Xianggang quanli jiegou 重組香港權力結構). The dichotomous divide created by the Occupy movement in Hong Kong society will likely aggravate social tensions and provide favourable conditions for Beijing to strengthen divide-and-rule. (39) Even in the worst-case scenario of Hong Kong descending into chaos, Beijing will not offer any concessions but will be justified in acting with greater force. In a similar line of reasoning, Beijing loyalist Jasper Tsang Yok-sing argued that in light of Beijing's tough-

28. Joyce Ng, "Top court judge questions 'odd' injunction," SCMP, 13 November 2014.

29. "Court not solving political issue: SJ," Hong Kong Information Service Department, 18 November 2014, available at http://www.news.gov.hk/en/categories/law_order/html/2014/11/20141118_ 110127.shtml.

30. Statement of Hong Kong Bar Association in respect of "Mass Defiance of Court Orders," Hong Kong Bar Association, 28 October 2014.

31. James Pomfret, "In HK, China likely to use pressure, intimidation to ward off more protests," Reuters, 12 December 2014

32. Enda Curran, Charles Hutzler, and Kathy Chu, "Hong Kong Protests Set to Leave Lasting Impact on Ties With China," The Wall Street Journal, 7 October 2014.

33. Danny Lee and Gary Cheung, "Beijing tells Britain it has no 'moral responsibility' for Hong Kong," SCMP, 3 December 2014

34. "Full text: Chinese State Council white paper on 'One Country, Two Systems' policy in Hong Kong," SCMP, 10 June 2014.

35. Chris Yeung, "Sense and sensibility lost in 'love China' row," HKEJ forum, 11 March 2013.

36. Ibid.

37. Helen Lai, "Zhongnanhai chongsu xianggang guanzhi shi, xinshidai tupo jieshi quanqiuhua" (Zhongnanhai reshapes Hong Kong's governance, new generation seek breakthrough from globalisation), Ming Pao, 30 November 2014, available at http://vicsforum.blogspot.hk/2014/11/blogpost_749.html; summarised by Frank Chen, "How Beijing is benefiting from the democracy protests," EJ Insights, 4 December 2014, available at http://www.ejinsight.com/20141204-howbeijing-is-benefiting-from-the-democracy-protests/.

38. "Hong Kong lawmaker James Tien axed from CPPCC after calling for CY Leung to resign," SCMP, 30 October 2014

39. Fanny W. Y. Fung, Alice Woodhouse, Jennifer Ngo, and Amy Nip, "A city divided: Occupy protest and rally by opponents mark a society split by politics," SCMP, 26 October 2014. 
ening stance, it would be more judicious to accept the current electoral reform package, as the maintenance of "One Country, Two Systems" hinges on Beijing's trust in the Hong Kong populace. A more confrontational attitude, he warned, would result in tighter controls from the central government, thus hampering the democratic prospects of the region. ${ }^{(40)}$

While it is not clear the extent to which Beijing could reshuffle Hong Kong's political structure or the process it would take, other observers appeared to be more optimistic, contending that the Occupy movement has given rise to a more robust civil society. In a newspaper interview reviewing the 79-day occupation, Benny Tai said that he believed the campaign had widened the support base of the pro-democracy camp. Even though "more people became anti-Occupy [towards the end] because they found it went on too long," Tai cited a Chinese University poll showing that supporters of Occupy accounted for more than $30 \%$ of respondents, which he believed was "solid growth" from when he first floated the idea of Occupy Central. (41) Dr. Chan Kin-man, a sociologist and co-organizer of OCLP, said that even though the Occupy movement had achieved nothing on institutional change, it had scored exceptionally well in terms of strengthening civil society and enlightening Hong Kong people to fight for democracy. ${ }^{(42)}$ For cultural commentator An Tu, the Occupy movement represents the triumph of a self-organised (zifa zhuyi 自發主義) protest movement with decentralised, bottom-up leadership, and is likely to accumulate and transform into stronger civil society forces. ${ }^{(43)}$ On the other hand, sociologist Hung Ho-fung refused to consider the "political awakening" set off by the movement as a "partial success" (jieduanxing shengli 階段性勝利), (44) but argued that it has catalysed a paradigm shift in the city's democracy movement and the making of an autonomous civil society (zizhu gongmin shehui 自 主公民社會). ${ }^{(45)}$

These positive civil society accounts, however, might overstate reality given the internal strife between the radical and moderate protesters throughout and after the Occupy movement, which might result in a more fragmented pro-democracy camp in the post-Occupy era. (46) But even so, a fragmented (but active) civil society could bring more clashes with Beijing under its hardened stance on Hong Kong. In addition, although the true impact of the Occupy movement will take time to emerge, it is certain that the lack of concessions from the Hong Kong government and Beijing, added to the unproductive government-protester talks on October 21, (47) will deepen mistrust between power-holders and the city's pro-democracy politicians and supporters. ${ }^{(48)}$ Moreover, the uncompromising approach is likely to squeeze out any remaining hopes for dialogue and negotiation, leaving street protests or more radical actions as the only options to express dissent. The "shopping tour" (Cant.: gau wu tyun 鳩鳴團) (49) protests, characterised by their fluid, spontaneous, leaderless, and quotidian nature, where protesters rallied for democracy on the pretext of shopping, have offered a hint of the emerging forms of political activism in post-Occupy Hong Kong. ${ }^{(50)}$ With tightening control from Beijing and a more active (and volatile) civil society, Hong Kong is set to enter a new protest era, with the ambiguities of "One Country, Two Systems" continuing to fuel the tug-ofwar between the Chinese authorities and the Hong Kong pro-democracy activists.

\section{Conclusion}

Despite the uncertain impact of the Occupy movement, the 79-day occupation has significantly transformed Hong Kong politics. Not only will the Hong Kong populace - especially the younger generation - become more politically active, they will also adopt novel, and more radical, means of protest to reiterate demands for universal suffrage and to push for greater autonomy. Nevertheless, it is important to note that the Umbrella Movement did not resolve the problems that contributed to its emergence in the first place; on many levels, as is shown by this article through the debate on the rule of law and Hong Kong's constitutional relations with China, the movement has deepened the social rift, leaving the city with a more fragmented and divided society and less room for compromise over disagreements. In combination, these factors will likely give rise to more complex and confrontational state-society relations in the post-Occupy era.

"It's just the beginning," read a large yellow banner hung by protesters hours before the Admiralty protest camps were cleared. Indeed, the beginning of an uncertain future as well.

\section{Samson Yuen is a PhD candidate in politics at the University of Oxford and is a research assistant at the CEFC (samson.yuen@sant.ox.ac.uk).}

CEFC News Analysis is compiled from the CEFC's fortnightly selection of Press Highlights, available at www.cefc.com.hk.

40. Zhang Jieping, "Zeng Yucheng: women zoujin le yige exing xunhuan" (Tsang Yok-sing:We have entered a vicious cycle), The New York Times Chinese Edition, 10 October 2014, available at http://cn.nytimes.com/china/20141010/cc10zengyucheng/zh-hant/.

41. Joyce Ng, "Hong Kong's Occupy protests did not end with a loss, says co-founder Benny Tai," SCMP, 22 December 2014.

42. Yu Wei, "Chen Jianmin: buzai gao sheyun, yongbi kangzheng" (Chan Kin-man: I will never be a social movement organiser, but I will protest with my pen), Ming Pao, 9 December 2014, available at http://specials.mingpao.com/cfm/News.cfm?Specials|D=137\&News=cab914df23750540c8fe 411732d47722acdc4d61b276542c808c59392a76640d8a82.

43. An Tu, "Zhanling zhihou: "hou zhanling" shidai de juewang zhandou" (After Occupy: A desperate battle in the post-Occupy era), Ming Pao, 13 December 2014, available at http://vicsforum.blogspot.hk/2014/12/blog-post_47.html.

44. Hung Ho-fung, "Zhanling qishilu" (The revelation of the Occupy movement), Ming Pao, 8 December 2014, available at http://vicsforum.blogspot.hk/2014/12/blog-post.html.

45. Hung Ho-fung, "Zhanling yundong shi zizhu gongmin shehui de chengrenli" (The Occupy movement is the maturation of a self-autonomous civil society), Ming Pao, 14 October 2014, available at www.pentoy.hk/時事/k22/2014/10/14/孔誥烽：佔領運動是自主公民社會的成人禮/.

46. Lily Kuo, "Hong Kong's Umbrella Movement is starting to splinter," Quartz, 7 November 2014, available at http://qz.com/292835/hong-kongs-umbrella-movement-is-starting-to-splinter/.

47. Isabella Steger and Chester Yung, "Hong Kong Protesters, Government Hold First Talks on Future of Democracy," The Wall Street Journal, 21 October 2014.

48. Ma Ngok, "Cong weiji dao gengshen de weiji" (From crisis to a deeper crisis), Ming Pao, 24 November 2014, available at http://vicsforum.blogspot.hk/2014/11/blog-post_87.html.

49. The term "gau wu" is a Cantonese transliteration of the Mandarin "gou wu," which means shopping, to mock Mainland tourists' affinity for shopping in the city.

50. Samuel Chan, "The game changes: As Occupy sites are cleared, Hong Kong's democracy protesters go 'shopping'," SCMP, 11 December 2014. 